Original research article

\title{
Prevalence and risk factors of pneumonia in under five children living in slums of Dibrugarh town
}

\author{
Nabanita Nirmoliaa,*, Tulika G. Mahanta ${ }^{\mathrm{b}}$, Manjit Boruah ${ }^{\mathrm{a}}$, Reeta Rasaily ${ }^{\mathrm{c}}$, \\ Rita P. Kotoky ${ }^{\mathrm{d}}$, Rituparna Bora ${ }^{\mathrm{e}}$ \\ a Community Medicine, Assam Medical College, India \\ ${ }^{\mathrm{b}}$ Community Medicine, Tezpur Medical College, India \\ c Scientist F, ICMR, New Delhi, India \\ d Paediatrics, Assam Medical College, India \\ e Physiology, Assam Medical College, India
}

\section{A R T I C L E I N F O}

\section{Article history:}

Received 7 May 2017

Received in revised form 7 July 2017

Accepted 27 July 2017

Available online 29 July 2017

Keywords:

Pneumonia

Underfive

Slums

\begin{abstract}
A B S T R A C T
Background: Pneumonia is a severe form of acute lower respiratory infection responsible for high preventable morbidities and mortality amongst under five year child. Many risk factors and barriers for care seeking influencing the prevalence of ARI and pneumonia.

Methods: A community based cross sectional study was undertaken in two slums of Dibrugarh town that were randomly selected.

Subject: Selection was done by probability proportionate to size technique. A total of 624 children were examined by house to house visit.

Results: Prevalence of pneumonia was $16.34 \%$. Socio economic status $(\mathrm{p}=0.005)$, education of mothers $(p=0.000)$, timely initiation of complementary feeding $(p=0.006)$, complete immunization $(p=0.000)$ and indoor air pollution $(p=0.000)$, were significantly associated with occurrence of pneumonia. In multivariate analysis, pneumonia is significantly associated with indoor air pollution.

Conclusion: High prevalence of pneumonia and its association with different preventable risk factors needs to be addressed. Different community based intervention can be implemented to reduce this preventable morbidities.
\end{abstract}

(c) 2017 INDIACLEN. Published by Elsevier, a division of RELX India, Pvt. Ltd. All rights reserved.

\section{Introduction}

Global Burden of Disease estimates 2010, stated that acute lower respiratory infection (ALRI) is the leading cause of death among children aged under five years in developing countries. ${ }^{1}$ About 13 Million children under 5 years of age die every year in the world, out of which 95\% of them are in developing nations, one third of total deaths are due to ARI. ${ }^{2}$ Estimate showed for developing nations, that more than 150 million episodes of pneumonia occur every year in under five years age group. ${ }^{3}$ India needs a special mention as India tops the list amongst the 15 countries having a high incidence of childhood pneumonia with 43 million episodes of pneumonia annually ${ }^{4}$

\footnotetext{
* Corresponding author.

E-mail addresses: nabanitanirmolia@yahoo.com, sailenroy13@yahoo.in (N. Nirmolia).
}

Though wide diversity is seen in different studies in assessing the risk factors in the focus, study design and outcome, undernutrition, use of solid fuels in a household, crowding, lack of exclusive breastfeeding, low degree of maternal education, limited access to secondary care and passive care-seeking behavior which are often characteristics of poor households are cited by many studies as the common risk factors for occurrence of ARI. ${ }^{5}$ Therefore, it is necessary to study the risk factors which may perpetuate the development of ARI and uderstanding which will further help in the prevention of ARI and its complications.

People living in the slum areas are usually a diversified community of different caste, creed, religion and occupation with compromised facilities like water supply, hygiene and sanitation, living condition, population density and so on. So the present study was intended to conduct in an urban slum amongst children under five years with the objectives, to assess the risk factors and prevalence of pneumonia in under five children living in slums of Dibrugarh town. 


\section{Methods}

Ethical consideration: Ethical approval was taken from Institutional Ethics Committee. Due permission before conducting the study was taken from Joint Director of Health Services. Informed written consent was taken from either of the parent of each participant after briefing about the research purpose, methods and involvement at the time of obtaining consent.

Sample size: A community based cross sectional study was undertaken from September 2015 to February 2015 in the slums of Dibrugarh town.There are ten numbers of registered slums and two slums were randomly selected. Taking annual cumulative incidence of pneumonia for 12-23- month as 38.3 per thousand with $95 \%$ confidence interval and $10 \%$ relative precision, the required sample size is 627 which were rounded upto $630 .^{6}$ The participants selected per slum were based on probability proportionate to size technique. All children between age group of 1-5 years were enlisted by house to house visit and the required number of children was selected from the list using random sampling.

The interview schedule was field tested and then data was collected by interviewing the caregivers who was mostly the mothers in many of the participants. All consenting under-five children without chronic respiratory ailments were included, while those with were excluded. Statistical analysis was done using rates, ratio, proportion, univariate and multivariate analysis.

\section{Results}

Response rate of the study was good as all selected participated. A total of 630 numbers of children were to be examined but as the data set came as incomplete in six of the participants hence 624 numbers were taken in analysis in the two slums Chandmari ghat and Graham bazar. According to modified Kuppuswamy 2014, socio economic classification, $42.3 \%$ belong to upper lower class, $32.5 \%$ belonged to lower middle class and $17.78 \%$ belonged to upper middle class, while $7.3 \%$ belonged to lower class.

$6.7 \%$ of mothers of the study participants received education upto high school and above while $24.35 \%$ mothers were illiterate. Pre-lacteal feeds were given to $53.52 \%$ babies. Exclusive breast feeding was done in $43.6 \%$ of the children. In $11.53 \%$ of children complementary feeding was started before 6 months while $68.75 \%$ received complementary feeding at six months. $61.53 \%$ of children were completely immunized while $36.85 \%$ were partially immunized and $1.6 \%$ didn't receive any immunization [Table 1]. In our study, the prevalence of pneumonia was found to be $16.34 \%$ [Table 2].

In univariate analysis, socio economic status based on Kuppuswamy classification 2014 is significantly associated with pneumonia occurrence. Also, education of mothers $(p=0.000)$, timely initiation of complementary feeding $(p=0.006)$, complete immunization $(p=0.000)$ and indoor air pollution $(p=0.000)$, are significantly associated with occurrence of pneumonia [Table 3].

In multivariate analysis, pneumonia is significantly associated with indoor air pollution [Table 4].

\section{Discussion}

About 120 million cases of pneumonia occur annually throughout the world of which 1.7 million die. ${ }^{7}$ Many of the deaths are preventable with simple interventions and can be treated with low cost technologies and care. ${ }^{8}$

In our study lower socio economic status is significantly associated with occurrence of pneumonia. Lower income is cited as a risk factor for ARI. ${ }^{8}$ Similar result was shown in another study done in Hooghly district of West Bengal. ${ }^{9}$
Table 1

Distribution of the study group according to different variables.

\begin{tabular}{|c|c|c|}
\hline Variables & Number & Percentage (\%) \\
\hline \multicolumn{3}{|l|}{ Socio economic status } \\
\hline Upper Middle Class and above & 111 & 17.78 \\
\hline Lower Middle class & 203 & 32.5 \\
\hline Upper Lower Class & 264 & 42.3 \\
\hline Lower Class & 46 & 7.3 \\
\hline \multicolumn{3}{|l|}{ Maternal education } \\
\hline Illiterate & 152 & 24.35 \\
\hline Upto primary & 148 & 23.71 \\
\hline Upto matric & 282 & 45.19 \\
\hline High school and above & 42 & 6.7 \\
\hline \multicolumn{3}{|l|}{ Prelacteal feed } \\
\hline Given & 334 & 53.52 \\
\hline Not given & 290 & 46.47 \\
\hline \multicolumn{3}{|l|}{ Breast feeding } \\
\hline Exclusive Breast feeding & 272 & 43.6 \\
\hline Breast milk and water & 68 & 10.9 \\
\hline Others & 284 & 45.5 \\
\hline Variables & Number & Percentage (\%) \\
\hline \multicolumn{3}{|l|}{ Complementary feeding } \\
\hline Less than 6 months & 72 & 11.53 \\
\hline At 6 months & 429 & 68.75 \\
\hline More than 6 months & 123 & 19.71 \\
\hline \multicolumn{3}{|l|}{ Immunization } \\
\hline Complete & 384 & 61.53 \\
\hline Partial & 230 & 36.85 \\
\hline Not immunized & 10 & 1.6 \\
\hline \multicolumn{3}{|l|}{ Indoor air pollution } \\
\hline Yes & 434 & 69.55 \\
\hline No & 190 & 30.44 \\
\hline
\end{tabular}

Table 2

Distribution of study participants according to presence of pneumonia (based on fast breathing and chest indrawing).

\begin{tabular}{llc}
\hline \multirow{2}{*}{ Sex } & \multicolumn{2}{c}{ Pneumonia } \\
\cline { 2 - 3 } & Yes & No \\
\hline Male & $54,(52.94 \%)$ & $241(46.16 \%)$ \\
Female & $48,(47.06 \%)$ & $281(53.83 \%)$ \\
Total & $102,(16.3 \%)$ & $522(83.7 \%)$ \\
\hline
\end{tabular}

Lack of awareness and education of the mothers may adversely have an impact on the outcome of the illness which may be amenable to public health intervention. ${ }^{10}$ Our study showed lack of maternal education is significantly associated with occurrence of pneumonia. Educated mothers recognize the signs and symptoms of pneumonia early and so accesses health care earlier and so their children have a better outcome than others. ${ }^{11}$ A study conducted in Nigeria reveals that poor parental educational status is significantly associated with ARI. ${ }^{12}$

In the present study, prelacteal feeding was not significantly associated with occurrence of pneumonia. K Hemagiri et al in their study have found significant association of prelacteal feeding with childhood pneumonia. ${ }^{13}$ Age at onset of complementary feeding may also be associated with pneumonia occurrence. Occurrence is $21.3 \%$ when feeding was started at 4 months, $13.7 \%$ at six months and $30.7 \%$ beyond six months of age. ${ }^{14}$ Our study too shows statistical association of complementary feeding in time with pneumonia occurrence.

Immunization of children with two doses of measles vaccine through routine immunization, immunization with three doses of pentavalent vaccine and also booster doses of DPT vaccine during childhood can go a long way for prevention of pneumonia occurrence. Reduction in occurrence of pneumonia have been observed in completely immunized child as according to age, as 
Table 3

Univariate analysis to show factors associated with pneumonia.

\begin{tabular}{|c|c|c|c|c|}
\hline \multirow[t]{2}{*}{ Status } & \multirow[t]{2}{*}{ Variables } & \multicolumn{2}{|l|}{ Pneumonia } & \multirow[t]{2}{*}{ P-value } \\
\hline & & Yes $(\%)$ & No $(\%)$ & \\
\hline \multirow[t]{4}{*}{ Socio economic status } & Upper middle class and above & $6,(5.4)$ & $105,(94.6)$ & \multirow[t]{4}{*}{0.005} \\
\hline & Lower middle class & $37,(18.22)$ & $166,(81.78)$ & \\
\hline & Upper lower class & $48,(18.19)$ & $216,(81.81)$ & \\
\hline & Lower class & $11,(23.91)$ & $35,(76.09)$ & \\
\hline \multirow[t]{4}{*}{ Mothers education } & Illiterate & $37,(24.35)$ & $115,(75.65)$ & \multirow[t]{4}{*}{0.000} \\
\hline & upto primary & $36,(24.33)$ & $112,(75.67)$ & \\
\hline & upto matric & $26,(9.22)$ & $256,(90.78)$ & \\
\hline & High-school \& above & $3,(7.15)$ & $39,(92.85)$ & \\
\hline \multirow[t]{2}{*}{ Prelacteal feed } & Yes & $56,(16.77)$ & $278,(83.23)$ & \multirow[t]{2}{*}{0.554} \\
\hline & No & $43,(14.82)$ & 247, (85.17) & \\
\hline \multirow[t]{3}{*}{ Feeding in first six months } & Exclusive breast milk & $42,(15.4)$ & $230,(84.6)$ & \multirow[t]{3}{*}{0.237} \\
\hline & Breast milk + Water & $16,(23.5)$ & $52,(76.5)$ & \\
\hline & Others & $44,(15.50$ & $240,(84.5)$ & \\
\hline \multirow[t]{3}{*}{ Start of complementary feeding } & Less than 6 months & 19, (26.4) & $53,(73.6)$ & \multirow[t]{3}{*}{0.006} \\
\hline & Equal to 6 months & $57,(13.3)$ & $372,(86.7)$ & \\
\hline & Greater than 6 months & 26, (21.14) & $97,(78.86)$ & \\
\hline \multirow[t]{3}{*}{ Immunization } & Complete_immunization & $37,(9.64)$ & $347,(90.36)$ & \multirow[t]{3}{*}{0.000} \\
\hline & Partial & $64,(27.82)$ & $166,(72.17)$ & \\
\hline & Never immunized & $1,(10.0)$ & $9,(90.0)$ & \\
\hline \multirow[t]{2}{*}{ Indoor_air_pollution } & Yes & $97,(22.3)$ & $337,(77.7)$ & \multirow[t]{2}{*}{0.000} \\
\hline & No & $5,(16.3)$ & $185,(83.7)$ & \\
\hline
\end{tabular}

Table 4

Multivariate analysis to show association of factors with pneumonia.

\begin{tabular}{|c|c|c|c|c|}
\hline \multirow[t]{2}{*}{ Variables } & \multirow[t]{2}{*}{$P$ value } & \multirow[t]{2}{*}{ OR } & \multicolumn{2}{|c|}{$95 \% \mathrm{CI}$ for $\mathrm{OR}$} \\
\hline & & & Lower & Upper \\
\hline \multicolumn{5}{|l|}{ Socio economic class } \\
\hline Upper middle class and above & .297 & 1.894 & .570 & 6.292 \\
\hline Lower middle class & .379 & .672 & .277 & 1.629 \\
\hline Upper lower class & .995 & 1.003 & .439 & 2.291 \\
\hline Lower class & Ref & & & \\
\hline \multicolumn{5}{|l|}{ Mother's education } \\
\hline Illiterate & .475 & .611 & .158 & 2.362 \\
\hline Upto primary & .520 & .646 & .170 & 2.452 \\
\hline Upto matric & .528 & 1.533 & .407 & 5.778 \\
\hline High school and above & Ref & & & \\
\hline \multicolumn{5}{|l|}{ Complementary feeding } \\
\hline Starting less than six months & .781 & .899 & .425 & 1.904 \\
\hline Starting at six months & .192 & 1.457 & .828 & 2.566 \\
\hline Starting beyond six months & Ref & & & \\
\hline \multicolumn{5}{|l|}{ Immunization } \\
\hline Complete & .644 & .605 & .072 & 5.093 \\
\hline Partial & & & .020 & 1.427 \\
\hline Never & Ref & & & \\
\hline \multicolumn{5}{|l|}{ Indoor air pollution } \\
\hline Yes & .000 & .135 & .052 & .355 \\
\hline No & Ref & & & \\
\hline
\end{tabular}

complete vaccination status is a marker for increased access to health care services, better child care practices. ${ }^{10}$ Studies conducted in Nigeria have reported that $50 \%$ of poorly immunized children also had suffered from severe form of ARI like pneumonia. ${ }^{12}$ Another study has reported a lower incidence of ARI in children who are completely immunized than those with incomplete immunization. ${ }^{15}$

Urban poor communities mostly use wood or dried animal dung as fuel. Since in many situations cooking and living occur in the same room, the children are exposed to indoor air pollution which perpetuates ARI and pneumonia in many occasions. ${ }^{4}$ There are documentations that the risk of pneumonia is enhanced following exposure to unprocessed solid fuel use by a factor of $1.8^{16}$ and also there is significant association between ARI and indoor air pollution. ${ }^{17}$ Our study have documented a significant association between indoor air pollution and pneumonia.It has been recommended that prevention of indoor air pollution from burning of solid fuel to switching over to better quality fuel, improved ventilation or some other measures will substantially reduce morbidity and mortality from pneumonia. ${ }^{16}$

\section{Conclusion}

It can be concluded that in a developing country like India, pneumonia is a common childhood illness with risk factors like lower maternal education, delayed onset of complementary feeding, lack of complete immunization, indoor air pollution and also lower socio economic condition which is a scenario usually observed in urban slums. Effective community based interventions like health education, generating awareness amongst the people living in the slums may go a long way in addressing the risk factors as well as reducing the burden of pneumonia in these areas.

\section{References}

[1]. IHME. Global Burden of Disease Compare. University of Washington; 2013 [cited 2013 3.11]; Available from: http://viz.healthmetricsandevaluation.org/gbdcompare/..

[2]. Rudan I, Boschi-Pinto C, Biloglav Z, Mulholland K, Campbell H. Epidemiology and etiology of childhood pneumonia. Bull World Health Org. 2008;86:408416.

[3]. Rudan I, Tomaskovic L, Boschi-Pinto C, Campbell H. Global estimates of the incidence of clinical pneumonia among children under five years of age. Bull World Health Org. 2004;895-903.

[4]. Ghimire M, Bhattacharya SK, Narain JP. Pneumonia in South-East Asia region: Public health perspective. Indian J Med Res. 2012;135:459-468.

[5]. Rudan I, Brien K, Nair H, liu L, Theodoratu E, Qazi S, Luksic E, Walker C, Black R, Campbell H. Epidemiology and etiology of childhood pneumonia in 2010: estimates of incidence, severe morbidity, mortality, underlying risk factors and causative pathogens for 192 countries. J Global Health. 2013;3(1):010401.

[6]. Sreeraman. Pneumonia Rates Among Indigenous Children Highest in the World. MJA; [49_TD\$DIFF][28_TD\$DIFF]2010http://www.medindia.net/news/ Pneumonia-Rates-Among-Indigenous-Children-Highest-in-the-World-MJA68987-1.

[7]. Marsh DR, Gilroy KE, de Weerdt RV, Wansid E, Qazie S. Community case management of pneumonia: at a tipping point? Bull World Health Org. 2008;86 (5).

[8]. http://www.who.int/mediacentre/factsheets/fs331/en/ .

[9]. Mitra NK. A longitudinal study on ARI among rural under fives. Ind J Commun Med. 2001;XXVI(1). 
[10]. Fonseca W, Kirkwood BR, Victora CG, Fuchs SR, Flores JA, Misago C. Risk factors for childhood pneumonia among the urban poor in Fortaleza, Brazil: A casecontrol study. Bull World Health Org. 1996;74(2):199-208.

[11]. Tiewsoh K, Lodha R, Pandey RM, Broor S, Kalaivani M, Kabra SK. Factors determining the outcome of children hospitalized with severe pneumonia. BMC Pediatrics; 2009.

[12]. Ujunwa FA, Ezeonu CT. Risk factors for acute respiratory tract infections in under-five children in Enugu Southeast Nigeria. Ann Med Health Sci Res. 2014;4 (1):95-99.

[13]. Hemagiri K, Sameena ARB, Aravind K, Khan Wahid, Vasanta SC. Risk factors for severe pneumonia in under five children-A hospital based study. Int J Res Health Sci. 2014;.

[14]. Prajapati B, Talsania N, Lala MK, Sonalia KN. A study of risk factors of acute respiratory tract infection (ARI) of under five age group in uban and rural communities of Ahmedabad district, Gujarath. Ann Med Health Sci Res. 2017;3 (January-June (1)) ISSN 2229-337.

[15]. Sharma D, Kuppusamy K, Bhoorasamy A. Prevalence of acute respiratory infections (ari) and their determinants in under five children in urban and rural areas of Kancheepuram district, South India. Ann Trop Med Public Health. 2013;513-518.

[16]. Dherani M, Pope D, Mascarenhas M, Smith KR, Weber M, Bruce N. Indoor air pollution from unprocessed solid fuel use and pneumonia risk in children aged under five years: a systematic review and meta-analysis. Bull World Health Organ. 2008;390-398C.

[17]. Taksande A, Yeole M. Risk factors of acute respiratory infection (ARI) in underfives in a rural hospital of Central India. J Pediatric Neonatal Individual Med. 2016;5(1):e050105. 